University of Wollongong

Research Online

Faculty of Law, Humanities and the Arts Papers (Archive)

Faculty of Arts, Social Sciences \& Humanities

2015

Chinese politics in Darwin: interconnections between the Wah on society and the Kuo Min Tang

J. Martinez

University of Wollongong, juliam@uow.edu.au

Follow this and additional works at: https://ro.uow.edu.au/lhapapers

Part of the Arts and Humanities Commons, and the Law Commons

Research Online is the open access institutional repository for the University of Wollongong. For further information contact the UOW Library: research-pubs@uow.edu.au 


\title{
Chinese politics in Darwin: interconnections between the Wah on society and the Kuo Min Tang
}

\author{
Abstract \\ In the 1920 and 1930s Chinese political activism in Darwin in northern Australia was roughly divided \\ between the Kuo Min Tang, founded in 1924, and the older Wah On Society. Darwin had a majority \\ Chinese population in 1911 and despite the effects of the White Australia policy the community \\ maintained strong numbers through its Australian-born children. Before 1924 the Wah On Society was the \\ main force in Chinese politics, concerning itself with community issues such as the temple, the aged and \\ maintaining links to China. Its members also addressed the Australian government on matters of \\ immigration, trade and employment - identifying themselves as the merchants of Darwin. With the advent \\ of the Kuo Min Tang, and the related Chinese Recreation Club in 1923, the role of the Wah On Society was \\ diminished. They maintained many responsibilities, such as celebrating Chinese New Year and raising \\ funds for China, but Kuo Min Tang and Chinese Recreation club officials were more vocal on women's and \\ workers' rights, segregation in sports, and immigration restriction. Differences of opinion arose between \\ young and old, the left and right wing, and over which group best served the Chinese Consul and the goals \\ of modern China.

\section{Disciplines} \\ Arts and Humanities | Law

\section{Publication Details} \\ Martinez, J. T. (2015). Chinese politics in Darwin: interconnections between the Wah on society and the \\ Kuo Min Tang. In S. Couchman \& K. Bagnall (Eds.), Chinese Australians, Politics, Engagement and \\ Resistance (pp. 240-266). Netherlands: Brill.
}




\title{
Chapter Eight
}

\section{Chinese Politics in Darwin: Interconnections between the Wah On Society and the Kuo Min Tang}

\author{
Julia Martínez ${ }^{1}$
}

In 1932, speaking at a gathering of the Chinese Commercial Society in Darwin in northern Australia, the Chinese Consul-General, Chen Wei Ping, sought to reassure the audience of merchants that he too was "a strong believer in the old traditions of the homeland." As a representative of the Chinese Nationalist Party or Kuo Min Tang (K.M.T.) (國民黨

Guomingdang), a party known for its modernising agenda, he diplomatically suggested that the Chinese people "must be very sure that the new things are good before they discard the old" (Northern Territory Times, hereafter NTT, 19 January 1932: 4). The rhetoric of new and old China was a common theme in Chinese political debate both in Australia and elsewhere in the diaspora during the 1920s and 1930s. Chinese politics had undergone many changes since the Revolution of 1911, as ideas that had been developing since the late 19th century were gradually put into practice. In particular, 'modern' thinkers challenged the teachings of Confucius relating to filial piety and obedience to fathers and husbands-ideas viewed as incompatible with the individual liberties espoused in modern politics (Chen 1999). Within modern Chinese politics there were also critical divisions. The K.M.T. itself underwent an emphatic shift towards the right after a split with the communists in 1927 and the inauguration of Chiang Kai-shek as president in 1929. This 1932 meeting with Darwin merchants was part of the rightist K.M.T. effort to improve relations with conservative Chinese. On the same day, Chen also met separately with the Darwin K.M.T. society, and there, as we shall see, the rhetoric was unabashedly in favour of a modernising agenda.

Despite Chen's attempt at diplomacy, the year 1932 in Darwin was to become one of overt political conflict between the local Chinese associations. There were at least four Chinese societies operating at this time. The oldest and largest society was the Wah On Society-written as 華安會館 Hua'an Huiguan in the Tung Wah Times (16 April 1932)—which was established in the 1880s. The term huiguan refers to an association of Chinese from the same ancestral district. The newer societies were the Chinese Recreation Club, established in 1923; the K.M.T., established in 1924; and the Chinese Commercial Society, first mentioned in 1931.2 Each group

\footnotetext{
${ }^{1}$ I would like to thank Dr Claire Lowrie for her helpful suggestions in drafting this chapter.

${ }^{2}$ Other associations, about which little is known, are the earlier Hung Sun Tung and Kung Y Tung which existed in the 1880s and early 1890s, and the later United Chinese Associations mentioned in 1940 .
} 
had its own aims, its own executive officials and its own politics, although arguably the Chinese Recreation Club operated in close affiliation with the K.M.T., while the Wah On Society and Commercial Society shared key members. In this chapter, I aim to situate the politics of the K.M.T. in the context of the older Wah On Society, considering how K.M.T. policies on issues such as religion, workers' rights and women in politics might have put them at odds with the older Chinese association. ${ }^{3}$

The town of Darwin had no Chinese-language newspapers, but debates over local Chinese politics were played out publicly in the two English-language newspapers, the Northern Territory Times and the Northern Standard. ${ }^{4}$ As Mei-fen Kuo has argued, newspapers are important historical sources, not merely because they reflect the opinions of the community but because they actively helped to shape Chinese politics (Kuo 2013: 7). Elsewhere in the diaspora we also find K.M.T. members using newspapers to promote their political agenda. In a wellknown case in San Francisco in 1927, an article published in the rightist K.M.T. newspaper Young China criticised the largest American huiguan, the Ning Yung Association. In response, the Ning Yung Association, with the support of leftist K.M.T. members, boycotted the newspaper for the next eight years (Lai 2004: 185). In the case of Darwin, neither newspaper gave overt preference to any particular Chinese association, although the Northern Standard, which was run by the North Australian Workers' Union, gave more column space to issues on workers' rights. With the recent digitisation of Australian newspapers through Trove (http://www.trove.nla.gov.au), we can now review the Darwin debates in more detail. This chapter also draws on the personal files on Chinese Australians held by the National Archives of Australia and photographs provided by the K.M.T. archives in Melbourne to provide a closer examination of the key players in local politics.

The Chinese population of Darwin was small but significant, with the 1933 census recording 316 Chinese by 'race' - which included the Australian-born-out of an overall Darwin population of 1566 (Commonwealth Statistician 1933). Of those 316 Chinese, only 30 were members of the K.M.T. in 1932 (Northern Standard, 12 April 1932: 6). In contrast, all Chinese, including K.M.T. members, appear to have been members of the Wah Oh Society according to Gee Ming Ket (Northern Standard, 25 August 1931: 1). The Darwin Chinese shared many fundamental political concerns, one being how best to mitigate the impact of the immigration restrictions of the White Australia policy. In this chapter, however, in keeping with Jennifer Cushman's call to study the Chinese community "on its own terms" (Cushman 1984: 101), I am less concerned with interethnic politics. Earlier work has shown how Chinese politics shaped their interactions with 'white' Australians, Aboriginal peoples and local Japanese in particular (Lowrie 2009; Martínez 2003, 2000; Ganter et al. 2006). My aim here is to explore the historical development of the different Chinese societies and their leaders, in order then to gain a more nuanced sense of the ruptures and interconnections of internal Chinese politics in Australia during this period.

\footnotetext{
${ }^{3}$ Some aspects of this discussion are drawn from my doctoral thesis (Martínez 2000).

${ }^{4}$ The Northern Territory Times and Gazette was renamed the Northern Territory Times in 1927 after the Northern Standard began publishing the Commonwealth government Gazette.
} 
Most Chinese in Darwin originated from Guangdong, with dialect groups including Sze Yup (四邑 Siyi), Heung-san (香山 Xiangshan) and Hakka (客家 Kejia) (Giese 1995: 43). The Chinese population in the Northern Territory had peaked in 1888 at just over 7000 (Markus 1994: 72). By the 1911 census, Darwin had only 364 male and 78 female Chinese, out of a total population of 1387, but the Chinese population (32 percent) still outnumbered both the European (27 percent) and Aboriginal populations (18 percent) (NAA: A1, 1911/16191). In 1921 out of the total Darwin population of 1399, there were only 181 people of Chinese nationality but 298 people in the category of Chinese by 'race' (Commonwealth Bureau of Census and Statistics 1921). By the 1930s the Australian-born Chinese had become numerically dominant in the Chinese community but the cultural-political distinction between this group and overseas-born Chinese should not be overstated. Most, if not all, of the Australian-born who participated in politics had been educated in China, were fluent in Chinese and demonstrated a strong sense of Chinese nationalism.

\section{The Wah On Society and Early Secret Societies}

In colonial Victoria, as Paul Macgregor (2013: 150) notes, where the population was predominantly Cantonese, there were separate district societies called gongsi (公司, also kongsi), such as the Sze Yup Society. He also describes how the term gongsi later came to be replaced with huiguan (Macgregor 2013: 153). In Darwin, which was also predominantly Cantonese, there is no evidence of there being separate district societies (NTT\&G, 14 August 1891: 2). Darwin was settled in 1869, much later than Victoria, and Chinese immigrants did not arrive until the 1870s. In the United States in 1882, the Chinese Consul-General had encouraged associations to merge into a single association, the Jinshan Zhonghua Huiguan (金山中華會館), also known as the Chinese Consolidated Benevolent Association of U.S.A., in order to become stronger to combat anti-Chinese legislation (Lai 2004: 50-52). Given that the Wah On Society was established around 1882 it is possible that they too had been asked to form a single society (Northern Standard, 8 April 1932: 2).

While the K.M.T. may have referred to the Wah On as a traditional association, the huiguan themselves were established as part of an early modernising agenda. A visitor to Darwin in 1882, William Sowden, commented that the "old conservatism of the Imperial Government of China is fast breaking up" and that the Chinese were becoming modern (Sowden 1882: 128). Modern organisation was needed to survive in an era of increasing anti-Chinese politics. By 1888 some 102 Chinese had applied to the South Australian government for naturalisation and had gained British subject status (Stone \& Steele 1995: 29). They also established a type of social security in the form of the Chinese Sick Relief Society in 1888. In 1889 a temple was built on the corner of Cavenagh and Bennett streets, which also served as a meeting hall (Northern Territory Times and Gazette, hereafter NTT\&G, 28 April 1888: 2; 19 January 1889: 3).

Our knowledge of Darwin Chinese community politics in the 19th century is limited. In his history of Chinese in the Northern Territory, Timothy Jones did not discuss the Wah On Society and made only brief mention of a number of secret societies. He noted that in 1889 Government Resident John Langdon Parsons blamed the Chinese for increasing lawlessness in Darwin. Parsons also reported that Chinese merchants had told him that the new temple was "all the 
same Fleemasonly" (Jones 2005: 70). In 1891 member for the Northern Territory, V.L. Solomon, put a Bill to the South Australian parliament to suppress Chinese secret societies in Darwin. He claimed to have the backing of Chinese merchants, who had approached Government Resident John Knight demanding the suppression of what they referred to as the "Triad Society", also called the "Sâng Hop Wee" association. The merchants claimed that this society, which was already outlawed in Singapore and Hong Kong, flourished "on the proceeds of crime" and had some 400 members in the Northern Territory (NTT\&G, 14 August 1891: 2). Such rivalry was common throughout Australia. In Melbourne in the same year there was hostility between the See Yup Society and the secret society called the Yee Hing Company (Fitzgerald 2007: 82). In Darwin, a warning comment in the newspaper advised the government not to get information from "an opposition society" which might be "foxing the authorities" to suit their own purposes (NTT\&G, 14 August 1891: 2). An Adelaide resident, W.P. Pearce, who was visiting family in the Northern Territory in 1891, took it upon himself to investigate and he reported that what was referred to as the "Triad Society" was in fact the Hung Sun Tung, which operated as a friendly society, providing food, board, employment and education (Advertiser, 1 September 1891: 6; Fitzgerald 2007: 57).

Darwin's prominent merchants belonged to the rival Kung Y Tung or "Tomahawk" Society. Adelaide merchant Way Lee, who had received a letter from Hung Sun Tung leaders Low Dun and $\mathrm{M}$. Kee, claimed that the Tomahawk Society was seeking revenge after some Tomahawk members had been arrested for gambling after a tip-off by a Hung Sun Tung member. Way Lee suggested that Solomon would do better to put forward a Bill to suppress gambling and opium (Advertiser, 1 September 1891: 6). There were six Chinese gambling houses in Darwin (Reynolds 2003: 111).

It is not known how the Wah On Society, as it came to be in 20th century, related to these early secret societies. Certainly the Wah On Society claimed responsibility for looking after the temple. They also organised Chinese New Year celebrations, cared for the elderly, maintained the Chinese cemetery and sent the bones of the deceased back to China (Northern Standard, 8 April 1932: 2). The only other suggestion of a Masonic connection appears later, in 1934, when the rebuilt temple in Darwin was referred to as the Chinese Masonic Temple (Northern Standard, 28 September 1934: 10).

In 1910 the President of the Wah On Society was Ah Cheong, who was born in Hong Kong around 1870. He was fluent in English, having come to Darwin aged 13 to live with his uncles Chin Mee Leung and Chin Wah and work in their tailoring business, Wing Cheong Sing. After Chin Mee Leung died in 1913, Ah Cheong became principal partner of Wing Cheong Sing (Northern Standard, 29 March 1935: 6). He was also a passionate photographer and had own photographic studio (NTT\&G, 22 July 1915: 24).

When Justice Samuel James Mitchell was appointed Government Resident of the Northern Territory in 1910, Ah Cheong gave him a "most hearty welcome," stating that the Darwin Chinese "rejoice today in the Freedom and Justice of British Law under which we live, and are confident that the best traditions of British Rule will be safe in your hands" (NTT\&G, 17 June 1910: 2). The welcome was primarily a matter of diplomacy, as Mitchell had already made enemies with the Darwin Chinese. In 1905 a group of Chinese merchants, led by Sze Yup 
merchant Chin Yam Yan, had published a critical letter in the Northern Territory Times in response to Mitchell's attack on the Chinese in the north. Chin Yam Yan declared that the real menace to the Territory was that it was "controlled for the most part by men like Mr. Mitchell, who know little about it and do not understand its problems" (cited in Jones 2005: 94). Just a year later Chin Yam Yan withdrew from Darwin politics. Despite being a naturalised British subject and having been in business in Darwin since 1880, he left Darwin in 1906 to return to China. Then aged 60 he had no intention of returning and passed the business name C. Yam Yan on to his young son Chin Pak Sue (NTT\&G, 10 August 1906: 2; NAA: A711, 1438; NAA: E752, 1916/51).

The Wah On Society name does not appear in Darwin newspapers for several years after 1910, during which time lobbying was done under the name of leading Chinese merchants. In the 1907 anti-opium campaign a group of 15 merchants, described as "Chinese Storekeepers", published a letter confirming their opposition to opium. They made no reference to the Wah On Society, but Ah Cheong (as Wing Cheong Sing) was part of that group. ${ }^{5}$ In 1912 protests over anti-Chinese labour legislation were again signed by the Chinese "storekeepers" and "businessmen" (NAA: A1, 1912/10547). The Wah On Society was not mentioned again until 1922, when the town council published ordinances governing the Chinese Cemetery (NTT\&G, 14 October 1922: 8).

The Wah On Society was, however, mentioned in the Sydney-based Chinese-language newspaper the Tung Wah Times (21 August 1920: 7). ${ }^{6}$ In 1920 they sent a letter to the N.S.W. Chamber of Commerce asking other Chinese associations to join them in a protest over the excessive shipping fees being charged to Chinese passengers travelling from Hong Kong to Australia. The letter was written in a spirit of hopeful co-operation in contrast to the antagonism of later years.

\section{The Advent of the K.M.T.}

The K.M.T. operated in Australia before the 1920s, but in 1921 it was consolidated as the Chinese Nationalist Party of Australasia. Despite protests from the Melbourne Chinese, the Sydney branch, with the permission of a party delegate from China, placed itself as the head of the new K.M.T. (Fitzgerald 2007: 130). Across Australia around this time there was evidence of power struggles between the K.M.T. and pre-existing huiguan and merchant associations. In Sydney, there was conflict between the Chinese Chamber of Commerce and the K.M.T., while in Melbourne the K.M.T. took control of the Victorian Chamber of Commerce in 1920 (Yong 1977: 88). When the Sydney K.M.T. was established in 1920, it at first worked in cooperation with the Chinese Masonic Society but relations became strained after a K.M.T. anti-gambling campaign. Sun Yat-sen had encouraged K.M.T. members to hold concurrent membership but after this the K.M.T. prohibited dual membership with the Chinese Masonic Society (Kuo \& Brett 2013: 40-41; Fitzgerald 2007: 133). In 1921, according to Anne Atkinson (1995: 43), the Perth K.M.T. replaced

\footnotetext{
${ }^{5}$ The letter was signed by Cheong Wo, Ah Hoy, Yet Loong, Yet Sing, Sun Hing Kee, Fong Cheong Loong, Sun Kwong Sing, Man Fong Lau, Hop Wah, Chong Kee, Wing Wah Loong, Chin Kim Kee, C. Yam Yan, Wing Cheong Sing and Wing Sang Tong (NTT\&G, 8 February 1907: 3).

${ }^{6}$ Thank you to Peter Gibson for this Tung Wah Times article.
} 
the older Chung Wah Association, but in fact the Chung Wah Association has continued to operate and in the 1920s was described as a charitable, non-political association in contrast to the K.M.T. (Daily News, 21 February 1928: 1; West Australian, 11 July 1929: 21).

The Darwin sub-branch of the K.M.T. was established on 5 May 1924 (Northern Standard, 6 May 1924: 2; Fitzgerald 2007: 128). At that time merchant Lee Chow, then aged 62, and known by his business name, Man Fong Lau, was Secretary of the Wah Oh Society. Lee Chow had organised the Chinese New Year procession that year with the help of Willie Howe, a 31-year-old Darwin-born storekeeper who was also Vice-President of the Chinese Recreation Club (NTT, 22 February 1924: 6; Northern Standard 22 February 1924: 3). Howe had also been named as representative of the Chinese community when the Minister for Home and Territories, George Pearce, visited Darwin in 1923 (Register, 18 May 1923: 8). Despite being Australian-born, Howe was a frequent visitor to China, travelling overseas six times between 1912 and 1923 (NAA: E752, 1921/20).

Two weeks after the Darwin K.M.T. was opened Lee Chow became seriously ill after a fall, apparently caused by a stroke. The Northern Territory Times extended their deepest sympathy to him and his family, describing him as a "Chinese Philanthropist" (30 May 1924: 5). When he died, one year later, wreaths were sent from the Wah On Society, the K.M.T. and the Chinese Recreation Club (Northern Standard, 29 May 1925: 2).

The Wah On Society continued to maintain an active role, being described in 1924 as "a very live institution" which was raising funds for flood relief in China (Townsville Daily Bulletin, 20 August 1924: 11). In 1926 both Ah Cheong and Willie Howe were cited as community leaders by the Darwin Town Council, on a matter relating to footpaths in Chinatown (Northern Standard, 3 September 1926: 3). These local government issues were not part of the K.M.T. agenda. When Ah Cheong died in 1935 his obituary described him as having been the leader of the Chinese community before the days of the K.M.T., but explained that when "politics had split their ranks he more or less dropped out of sight only continuing to take an active interest in the Wah On Society" (Northern Standard, 29 March 1935: 6).

\section{Religious Observances: Temple and Church}

As leader of the Wah On Society, Ah Cheong, unlike most K.M.T. members, was not a practicing Christian-he was buried according to Chinese rites in the Darwin Chinese cemetery (Wilson 1996: 3-4). The K.M.T. did not take leadership in matters of traditional Chinese religious life. Most young K.M.T. members appear to have followed Christian practices. In the 1911 census most Darwin Chinese gave their religion as Confucianism but by 1933 this had dwindled to only 4 per cent of the Chinese population. On the other hand, as Diana Giese has argued, becoming Christian did not prevent people from also attending the temple (Giese 1995: 43-44). Christianity was not a prerequisite for membership of the K.M.T., but in 1927, a Dr T.P. Woo, who was visiting Australia from Hong Kong, claimed that the K.M.T. was "essentially Christian and anti-Soviet", adding a political agenda to this declaration of Christianity (Northern Standard, 11 March 1927: 5). At this time the K.M.T. claimed that 80 per cent of adult Chinese residents in Australia were financial members, with 40 branches throughout Australia (Northern Standard, 28 January 1927: 6; 18 October 1929: 7). 
Despite the trend towards Christianity, there was sufficient community support in 1927 to be able to fund the building of a new temple in Darwin. Lee Ying, the new Secretary of the Wah On Society, asked the town council for permission to move the Chinese temple to Wood Street (where it now stands). ${ }^{7}$ The old building had been eaten by white ants but the new building was to be of iron and cypress pine (NTT\&G, 8 April 1927: 1).

In 1928, as in previous years, permission was sought from Mayor J.H. Brogan to have firecrackers for Chinese New Year celebrations. The application was signed by the usual Wah On members: Ah Cheong (Wing Cheong Sing), C.L. Fong and Mow Goon Pan, who was Lee Chow's successor as manager of Man Fong Lau (Northern Standard, 20 January 1928: 2). There was no mention of K.M.T. involvement.

Of the K.M.T. weddings that were reported in the newspapers, most were celebrated both with Christian rituals and K.M.T. official sanction. ${ }^{8}$ One significant Methodist wedding was that of Willie Lee Chow, son of the late Lee Chow, to Lucy Low See, daughter of Mrs Yet Loong (Northern Standard, 14 October 1930: 2) (Figure 8.1). In China, both leaders Sun Yat-sen and Chiang Kaishek had married Soong sisters, whose father was a Methodist minister (Bergère 1998: 251). Willie Lee Chow's wedding ceremony was performed by both the K.M.T. President, Chin Mon Dai, and Reverend Stanley Jarvis of the Methodist Missionary Society. Chin Mon Dai gave a speech supporting the Western-style marriage ceremony which allowed the bride and groom to greet each other and, so he argued, "did not carry the cruelties of the ancient form of oriental marriage" (Northern Standard, 14 October 1930: 2). During the evening, local barrister, J.S. Harris also gave a speech stating:

It was good to get together and talk over difficulties for then hard times would soon pass away. The union of two old families as these promised a good omen for the future. They could start to reconstruct again with a goodwill (NTT, 14 October 1930: 3).

\section{(PLACE FIGURE 8.1 HERE)}

\section{Figure 8.1 Wedding of Willie Lee Chow and Lucy Low See, 13 October 1930, K.M.T. Hall, Darwin}

Back row, left to right: Charlie Yuen, Chin Mon Dai, Willie Lee Chow, Gee Ming Ket, Kown Ling, Philip Lee Seated: Ruby Hassan, Selina Hassan, Lucy Lee Chow, Mrs Lee Chow, Lily Yuen Front row: Leslie Wong, Connie Hassan

PH0238/2055, Spillet Collection, Northern Territory Library

\footnotetext{
${ }^{7}$ In 1922 Lee Ying advertised as a fruiterer, greengrocer and pastrycook in Cavenagh Street. In 1924 he sold the Kwong Tung Café and in 1928 he was manufacturing cordials (NTT\&G, 9 September 1922: 1, 8 April 1924: 3; NTT, 9 March 1928: 6).

${ }^{8}$ Catholic K.M.T. weddings included the son of Chin Yam Yan, Willie Pak Poy, to Alberta Chee Quee (Northern Standard, 12 January 1926: 2). A secular K.M.T. wedding took place in 1931 between Clarence Ng and Dorothy Yuen (Northern Standard, 17 April 1931: 1).
} 
By 1934 Willie Lee Chow had joined the executive of the Darwin K.M.T. (Kuo \& Brett 2013: 87). Nearly one decade after his father's death, the son of the leader of the Wah On Society was now one of the leaders of the K.M.T.

\section{Merchants and the K.M.T. on Workers' Rights}

Historian John Fitzgerald (2007: 8) is sceptical about claims that Chinese were indentured into Australia, being particularly concerned with the notion that a culture of slave labour had been brought to Australia by Chinese immigrants. While representations of Chinese workers as slavelike 'coolies' were undoubtedly part of White Australian propaganda, both the term 'coolie' and the idea of Chinese as cheap labour were also propagated by the Chinese merchants of Darwin. In 1912, for example, when they protested against the removal of Chinese 'coolie' waterside workers and their replacement with white labour, their concern was for the unemployment this would cause but also with the greater cost to shipping (NAA: A1, 1912/10547). ${ }^{9}$

In a similar vein, in 1921, a deputation of Chinese merchants, including Wah On leaders Willie Howe, Chin Loong Fon and Man Fong Lau, approached the government asking for permission to indent "suitable labour from China for the purpose of working mines, growing cotton, rice or other tropical products." They argued for the economic benefits of cheap labour and pointed to the continued use of indentured labour in the pearling industry. They added that "white coolie labour" had been an "expensive failure" (NAA: A1, 1931/8945). A critical response from the Northern Standard (15 September 1921: 2) stated that "surely it must be apparent to everyone that the day of this class of labor is fast disappearing and will soon be only history of the dark past".

In contrast to the attitude of the merchants, Chinese workers in Darwin sought to secure their ongoing employment through unionism. In 1914 when the newly established Australian Workers' Union (A.W.U.) excluded Chinese workers from membership, Chinese waterside workers joined the Industrial Workers of the World (I.W.W.) in an unsuccessful attempt to keep their jobs. When the North Australian Workers Union (N.A.W.U.) was established in 1927 it retained the exclusionary membership clause that "no person who is a Chinese, Japanese, Kanaka, or Afghan, or who belongs to any colored race shall be admitted to membership." The only Chinese who were permitted to the join were those of mixed descent (Martínez 1999: 12). It would take more than two decades of lobbying before Chinese workers would be permitted to join the N.A.W.U. (Martínez 1999: 4; Brian 2001: 51).

The Northern Standard regularly published details of Chinese labour activism that served to build bridges between the labour movement and the local Chinese workers. In 1922, for example, they published news of a Chinese seamen's strike in Hong Kong and later acknowledged that in that same year Sun Yat-sen had demonstrated his support for the labour movement by legalising trade unions (Northern Standard, 28 March 1922: 4; 20 May 1927: 4).

\footnotetext{
${ }^{9}$ Claire Lowrie (2009) has also written on Chinese as masters of servants.
} 
The Sydney K.M.T. also had a good working relationship with communist Jock Garden from the Sydney Trades Hall (Fitzgerald 1997: 113-14). In 1925 K.M.T. support for Chinese seamen strikes helped to forge stronger relations with the Australian labour movement (Kuo \& Brett 2013: 50). In 1926 the K.M.T. established special branches for seamen (Kuo 2013: 9). Samuel Wong (黄來旺 Huang Laiwang), Chairman of the Sydney K.M.T., wrote of the Chinese Seamen's Union that "when a body of men held such humanitarian, and even Christian ideals, it was time that the shipping companies gave them better treatment" (Townsville Daily Bulletin, 10 August 1926: 4). In 1927, however, when Chiang Kai-shek broke the K.M.T. alliance with the communists, he introduced a purge of communists called the Party Purification Movement. In that year Wong's internationalist leanings led to his dismissal from the K.M.T. (Fitzgerald 2007: 139; Benton 2007: 75).

One of the leading Chinese activists supporting workers' rights in Darwin was the first president of the Chinese Recreation Club, Australian-born Gee Ming Ket (朱明傑 Zhu Mingjie). He worked as a tailor for Shing Lep and Co. and later took over that business (Northern Standard, 1 October 1926: 5) He was also on the executive of the K.M.T. in 1929. Gee Ming Ket was born in Darwin in 1900, son of Gee Kee Fow, a fisherman from the Daly River. He went to China aged five, returning to Darwin in 1911. At age 17 he went to China and married Fei Hai Ket, returning alone to Darwin in 1920 (Brisbane Courier, 20 June 1929: 19; NAA: E752, 1917/25).

In June 1928 the Chinese Recreation Club raised the issue of Chinese union membership with Harold Nelson, the member for Parliament for the Northern Territory. Nelson had been an organiser of the A.W.U. in 1914 but now recognised the Chinese as his constituents. Gee Ming Ket gave the welcome speech in English and K.M.T. Chairman David Sang spoke in Chinese (Northern Standard, 25 September 1928: 2). Nelson commented that hearing Gee Ming Ket's speech "one would be inclined to think that he was dealing with a candidate for parliament" (NTT, 25 September 1928: 3).

Frank Moo asked Nelson if he favoured Chinese being admitted to the union, to which Nelson replied that "if he were dictator he would throw open the union to all Australian-born" (NTT, 25 September 1928: 3). In March 1929 the N.A.W.U. voted on a proposal that would allow "any coloured person born in Australia who has passed a 3rd class school examination standard be admitted to membership", but only one-third of voters supported the amendment (Northern Standard, 1 March 1929: 5).

Despite that fact that the Australian K.M.T. had split with the communists after 1927 there was no evidence of a purge of communists from the Darwin K.M.T. They apparently maintained friendly relations with Australian communists, who continued to lobby for the removal of the N.A.W.U. colour bar. According to Henry Lee, the adopted son of the Lee Hang Gong family, during the communist-led demonstrations of 1930, the young men of the Lee family, who were on the K.M.T. executive, went along to show solidarity with the unionists (Lee 1981).

In 1935 Bob Murray, President of the N.A.W.U., announced a plebiscite of all members to remove the colour bar, but the amendment was defeated by a vote of six to one (Northern Standard, 11 June 1935: 9, 8 October 1935: 3; Brian 2001: 142). By 1940, however, a list of N.A.W.U. members 
includes several Chinese names, suggesting that the rules had finally been amended (Northern Standard, 9 January 1940: 11).

Gee Ming Ket continued to use the rhetoric of left-wing activists even in 1929 when the K.M.T. had become dominated by the right-wing. In 1929 he wrote:

When did the Conservatives of any country do any real and permanent good for the working classes? That sort of conservatism has held China in bonds of slavery for centuries (Northern Standard, 11 October 1929: 7).

But in that same year he supported the Consul-General's suggestion that Chinese labour be imported for tropical agriculture. This project was supported by the merchants and was described as being a resumption of the indentured labour trade (Cairns Post, 3 September 1929: $5)$.

This apparent contradiction in Gee Ming Ket's politics became more obvious by the 1930s. Between the years 1931 and 1934 he increasing aligned himself with the right-wing of the Sydney K.M.T., helping with the purge of two anti-Nationalist dissidents, Gee Fong Ming in Darwin (Northern Standard, 25 August 1931: 1) and later Vivian Chow, editor of Shanghai United China Magazine (Fitzgerald 2007: 149-50). He himself was forced to leave the K.M.T. in 1934 (Cairns Post, 18 January 1936: 6).

\section{Reponses to the Promotion of Women in the K.M.T.}

The Darwin K.M.T. was also known for its promotion of women members (Fitzgerald 2007: 130). Unlike the early years when the Chinese population had been predominantly male, by 1933 there were 196 males and 120 females of Chinese 'race' in Darwin (Commonwealth Statistician 1933). When Darwin journalist Jessie Litchfield applied for the job of editor of the Northern Territory Times in 1930, the owner expressed concern that his Chinese typographist "would object to taking orders from a woman." She had responded that Walter Que Noy was in the K.M.T. "which believed in the advancement of women" (Litchfield n.d.).

In 1921 the Australasian K.M.T. had obtained approval from Sun Yat-sen to open committee membership to women and to exempt women from membership fees. This Australian initiative predated the 1924 promotion of women's participation in politics in the China K.M.T. (Kuo \& Brett 2013: 23). Even so, a 1923 photograph of the office bearers of the K.M.T., taken in Melbourne, shows 37 young men and only one woman (Yong 1977: 155).

In 1924, a 22-year-old, well-educated young woman called Chong Shue Hing (鍾少卿 Zhong Shaoqing) arrived in Darwin from China. According to the birth certificate she used to enter Australia she was Leena Pak Fong and her father was the deceased merchant, Chin Yam Yan (James 1989: 122). On arrival in Darwin she married Willie Lee Hang Gong and became known 
as Lena Lee, or Mrs Willie Lee. ${ }^{10}$ She went on to become an important spokesperson for the Darwin K.M.T.. She also taught at the Chinese school and worked as a book keeper for Yuen See Kee (Martínez 2011: 211). Lena Lee made her first public appearance in 1927 when the Thai Royal Prince visited Darwin. The Northern Territory Times reported on the K.M.T. delegation that welcomed him, noting:

The committee is of interest as two ladies were co-opted to represent the New China. It is probable that this is the first instance in which Chinese ladies have officially participated in an Australian public function (NTT, 12 July 1927: 1).

The K.M.T. committee was listed as Chairman David Sang (Ching Ah Sang, manager of Chin Kim Kee), Secretary Chin Hee Hong and Gee Ming Ket, Lena Lee and Selina Yuen (NTT, 12 July 1927: 1). ${ }^{11}$

The K.M.T. Secretary, Chin Hee Hong, who had been teaching at the Darwin Chinese school, left Darwin on 19 November 1928 to travel to China. ${ }^{12}$ He wrote from Nanking in April 1929 to the Government Resident, Robert Weddell, explaining that he had been the North Australia representative at the election of Chiang Kai-Shek as President of the Republic (NTT, 8 June 1929: 10). With Chin Hee Hong absent, Lena Lee took on the role of secretary and went to the 1929 K.M.T. conference in Sydney (Northern Standard, 11 October 1929: 7). Of the eight Darwin delegates pictured below, six are mentioned in the Darwin newspapers, while only the two eldest men remain unidentified in English-language sources (Figure 8.2).

\section{[PLACE FIGURE 8.2 HERE]}

\section{Figure 8.2 Darwin delegates, K.M.T., $1929^{13}$}

Top row, left to right: Gee Ming Ket, Charlie Yee, Albert Fong, ${ }^{14}$ Arthur Lee Seated, left to right: Lau Wai Kwing, Lieng Yeoh Chee/Gee, Ching Ah Sang, Lena Lee Kuo Min Tang Society of Melbourne

The Northern Standard (8 October 1929: 1) claimed that having a woman as leader drew criticism from the older Chinese, writing:

\footnotetext{
${ }^{10}$ Willie Lee Hang Gong, born in Darwin in 1887, was grandson of merchant Lee Hang Gong and English woman Sarah Bowman, son of Arthur Edward and Emily Lee Hang Gong, and brother to K.M.T. official Arthur Lee (NAA: E752, 1916/61). See Appendix Two for their family tree.

${ }^{11}$ Ching Ah Sang (David Sang) was born in Darwin in 1893. His father was Ching Ling Hun. Ching Ah Sang was manager of Chin Kim Kee, but the business went bankrupt after 1929 (NAA: E752, 1924/10A; Northern Standard, 20 March 1928: 5, 31 December 1929: 5, 2 April 1931: 7).

${ }^{12}$ Chin Hee Hong was 47 years old in 1928. He was born in Hong Kong, came to Broome, Western Australia, in 1890 and moved to Darwin in 1924 (NAA: E752, 1928/52).

${ }^{13}$ I would like to thank Dr Mei-fen Kuo and Tsebin Tchen for supplying me with the K.M.T. photograph, which has helped me trace the names of the Darwin members of the K.M.T. See the Appendix One for a full list of their names in Chinese characters.

${ }^{14}$ Personal communication with Albert Fong's daughter Roberta Lowe, 27 February 2014.
} 
the old Conservative Chinese of Darwin will have nothing to do with this association whose chief say-so is a woman. Rightly it is pointed out that these people do not represent Chinese manners and thought.

Gee Ming Ket responded to this arguing that the conservatives "hate to see liberty and freedom being granted to Chinese women" (Northern Standard, 11 October 1929: 7). He described Lena Lee as "a highly respected and very clever lady" and noted that as the Darwin delegate in Sydney she had "acquitted herself with great honour" and that she had been received with the utmost courtesy by the Sydney merchants and the new Chinese Consul-General, F.T. Sung (Northern Standard, 11 October 1929: 7).

This Australian example of a Chinese woman in a position of leadership was rare even among the wider Chinese diaspora. In Judy Yung's study of Chinese women in San Francisco, she cites Jane Kwong Lee as one of the few "modern women in the 1930s" and yet Jane worked with the Chinese Y.W.C.A., as a leader of other women, which was quite different from being a leader in mainstream K.M.T. politics (Yung 1995: 195).

Lena Lee was also acting as Secretary for the Wah On Society, but as tensions escalated, she had apparently agreed that the two societies should conduct their own affairs separately (Northern Standard, 12 April 1932: 4). It seems, however, that Lena Lee was more concerned with the internal rifts appearing in the K.M.T. rather than the Wah On Society. Tragically, on 20 January 1930, Lena Lee took her own life with an overdose of opium (NTT, 24 January 1930: 6). She left two letters in Chinese, one to the K.M.T. and the other to her step-mother in China. The letters were translated into English by Gee Ming Ket at the coroner's inquest (NAA: E72, DL467). In her letter to the K.M.T. she wrote:

I joined the Darwin branch of the Nationalist Party shortly after I came here and it has for several years shown loyal support towards attaining its objects.

... I as a member have always tried to do my best towards the party but recently as the result of some alteration I am concerned considerably. So therefore I leave this note to inform you our loyal comrades that I will have to depart from you all forever. Those who are intelligent will follow Sun Yet Sen. (Lena Lee (Chong Shue Hing)) (NTT, 24 January 1930: 6; NAA: E72, DL467).

Lena Lee blamed the shift away from Sun Yat-sen's vision of the K.M.T. for her loss of faith.

Lena Lee's funeral took place at the Gardens cemetery, where Reverend Jarvis remembered her as a "Christian Chinese of exceptional education" and praised her for using her abilities "for the advancement of her compatriots." The Sydney K.M.T. sent a telegram stating that the "party loses a loyal, active worker" (NTT, 21 January 1930: 2). The Northern Territory Times wrote in memorial:

The deceased lady was one of the new era ladies of Chinese thought and education and a strong advocate for the emancipation of Chinese womanhood. Her death will leave a gap in the ranks of the Kuo Min Tang which will be hard to fill (NTT, 21 January 1930: 2)

With the death of Lena Lee, her sister-in-law Selina Hassan (nee Lee) and her brother-in-law Arthur Lee (李礽恭 Li Renggong) took her place. They were both Australian-born but Chinaeducated. The Lee Hang Gong family had moved to Hong Kong in 1904 when Selina was three 
and Arthur was seven. After their father, Arthur Edward, died in 1908, their mother, Louey Yat Tai (known as Emily or Minnie), and brother Willie returned to Darwin, but Selina, Arthur and Jack went to live with their father's second wife in Guangdong until 1910. It is for this reason that Selina and Arthur were fluent in Cantonese and English, qualities most admired by the K.M.T. (Hassan 1979).

Despite Lena's previous decision to keep K.M.T. and Wah On business separate, just a week after her death a letter from the Wah On Society to the Darwin Town Council concerning Chinese New Year was signed by the K.M.T.'s Arthur Lee as Secretary (Northern Standard, 31 January 1930: 4). Whether or not his role was imposed on the Wah On Society is not known.

In August 1930, and again in 1931, Arthur Lee represented Darwin at the K.M.T. conference in Sydney (NTT, 2 September 1930: 2). In 1931 a Special Commissioner from Nanking was present. The chairman of the convention spoke of Lena Lee as "an able and loyal member whose death was a great loss" and the "meeting stood in silence with bowed heads in memory of the late Sun Yat Sen and Mrs Lee" (Northern Standard, 17 February 1931: 2).

\section{Escalating Tensions with the K.M.T. in the 1930s}

Tensions between the Wah On Society and the K.M.T. only became worse in the 1930s. In 1931 there was a disagreement over who was responsible for sending the bones of the deceased back to China (Tung Wah Times, 29 August 1931: 8). The Wah Oh Society claimed that the K.M.T. was attempting to take over their role. Gee Ming Ket denied any friction between the two associations, claiming that his K.M.T. fundraising was for aged Chinese returning to China, while the $£ 300$ raised by the Wah On Society was for the return of bones to China (Northern Standard, 25 August 1931: 1). Gee Ming Ket also organised funds for Chinese flood relief, raising $€ 71 / 14 / 9$ in opposition to the Chinese Commercial Society which raised $£ 25 / 3 /-(N T T, 26$ January 1932: 4).15

At the Darwin K.M.T. celebration in 1931 to mark the 20th anniversary of the Chinese Republic, President Chin Mon Dai and Secretary Selina Hassan took the lead. Chin Mon Dai made a speech, honouring the "great Republic of China" in their efforts "to promote the advancement of China on modern civilised lines" and "to protect the interests of Chinese nationals abroad." Selina Hassan translated his speech into English. This reception was also a farewell for Gee Ming Ket, who was moving to Sydney to become editor of the K.M.T. Chinese Times (Northern Standard, 13 October 1931: 1). In 1931 Gee Ming Ket had been authorised by the new Consul-General, Kwei Chih, to issue Chinese passports, as it was now mandatory to have a passport to enter China (Northern Standard, 17 April 1931: 2). Despite this new role, he had to leave Darwin, having been forced to declare himself bankrupt (Northern Standard, 20 March 1931: 2).

\footnotetext{
${ }^{15}$ Contributors for the Commercial Society included Lee Lim, C. Yam Yan and Wing Cheong Sing (Ah Cheong). The K.M.T. fundraiser was organised by Lee Sing and Selina Hassan. Lee Sing, the eldest son of Lee Chow, had returned from nine years in China to take over Man Fong Lau (Northern Standard, 9 October 1931: 1; NTT, 6 October 1931: 4).
} 
In December 1931 Dr Chen, who replaced Kwei Chih in September, appointed Arthur Lee as Acting Deputy for the Consul-General. In 1932 Selina Hassan became Acting Deputy in his place (NTT, 8 December 1931: 2; 21 June, 1932: 2; Northern Standard, 9 October 1931: 1). The Darwin K.M.T. executive in 1932 was made up of President Chin Mon Dai, Secretary Selina Hassan and committee members Arthur Lee, Charlie Yee Hong On, Lew Wah, Leung Soo and Leung Sing (Northern Standard, 12 April 1932: 6).

When Dr Chen arrived in Darwin he first visited Administrator Robert Weddell, then he went to the K.M.T. Hall, and then he drove to the Chinese Commercial Society reception at the Kafcaloudes Buildings. The reception was hosted by Lee Lim as Secretary of the Commercial Society. Lee Lim had come to Australia from Guangdong in 1884 and was managing director of Wing Sang Tong (NTT\&G, 1 February 1927: 3). Even though Lee Lim was one of the older and presumably more conservative Chinese merchants, the Commercial Society was not entirely a bastion of 'old conservative' Chinese. The merchants of Darwin were increasingly young and Australian born. C. Yam Yan \& Co. was now under the management of Chin Yam Yan's fifth son, William Pak Poy, who was just 26 years old (NTT, 8 March 1929: 5; NAA: E752, 125/14A). His marriage in 1926 had been held in the Catholic Church, with the K.M.T.'s Arthur Lee as best man and Selina Hassan hosting the wedding reception (Northern Standard, 12 January 1926: 2).

Two of the speakers at the Chinese Commercial Society reception were both merchants and K.M.T. members, namely Lee Sing of Man Fong Lau and Albert Fong, who had been on K.M.T. executive in 1929 (Northern Standard, 24 May 1929: 2; NTT, 19 January 1932: 4). Albert Fong (Fong Kang Yuen, 鄐庚源 Kuang Gengyuan) was born in Australia in 1908, the son of Taishanese merchant Fong Sui Wing (c. 1860-1920) (Couchman 2012). He also was known by his business name Fong Yuen Kee (Gee 2008). Lee Sing's business interests included oil refining and motor cars in Guangdong and Macau (NTT, 6 October 1931: 4).

Following the Chinese Commercial Society reception, Dr Chen was guest at a K.M.T. banquet. Chin Mon Dai gave a speech, apologising that "We are not numerous and wealthy like what may be expected in Southern cities, but our welcome is nonetheless sincere" (NTT, 19 January 1932: 5). Figure 8.3 shows Dr Chen sitting with Selina Hassan and Chin Mon Dai on either side. Some 300 guests, including men from the unemployed camp, attended the banquet. Speeches were made in both Chinese and English and were translated by Selina Hassan (Sydney Morning Herald, 20 January 1932: 12).

\section{[PLACE FIGURE 8.3 HERE]}

\section{Figure 8.3 Darwin K.M.T., 24 January 1932}

PH0771/0010, Chan Collection, Northern Territory Library

By April 1932 the relationship between the Wah On Society and the K.M.T. had escalated to outright hostility. The Secretary of the Wah On Society at this time was Chin Ack Ming, the son of merchant Chin Toy who had come to Darwin around 1883 (Stone \& Steele 1995: 31). Chin Ack Ming was manager of his father's store Fang Chong Loong, which was now responsible for keeping the books for the Wah On Society. After a partial victory of the Chinese over the Japanese in February 1932, the K.M.T. asked the Wah On Society to celebrate with flags and 
firecrackers. Chin Ack Ming called a meeting of the Wah On Society where they decided to donate firecrackers but not to fly the Chinese flag on the grounds that "we were in Australia and not in China, and members did not like to fly flags on business premises as there was a lot of Japanese in town." Chin Mon Dai responded with a warning letter, stating: "In future any motions decided by the K.M.T. are for uniting the Chinese and you must not think otherwise, and you must carry [them] out without alteration" (Northern Standard, 8 April 1932: 7). Chin Ack Ming called another Wah Oh Society meeting, attended by the K.M.T. members, during which a fight broke out that resulted in participants on both sides being convicted of assault (Northern Standard, 8 April 1932: 7; Tung Wah Times, 16 April 1932).

Albert Fong gave evidence in court that the Wah On Society could not understand why the K.M.T. was insisting on telling them what to do (Northern Standard, 12 April 1932: 4). At the end of the court case Magistrate Norman C. Bell blamed the affair on Chin Mon Dai, stating: "I regard him as the cause of the whole trouble, which did damage to the reputations of those foolish enough to have followed him" (NTT, 3 May 1932: 2). At this time Chin Mon Dai was working as book keeper for Yee Ling and Wing Cheong Sing-both former secretaries of the Wah On Society. ${ }^{16}$

During the court proceedings Mr Fitzgerald, the lawyer representing Wah On member Lee Cheong Kwong, claimed that there was "seething" in Chinatown between the two societies. He described the Wah On Society as established for more than 50 years with philanthropic aims, whereas the K.M.T. he dismissively described as being eight or nine years old with only 30 members of mostly young people. He claimed that the Chinese merchants were members of the K.M.T. of China, but that they refused to join "the Darwin society on account of the character of some of the leaders" (Northern Standard, 8 April 1932: 2).

When the Tung Wah Times (16 April 1932) reported the story there was no mention of the K.M.T. forcing the Wah On Society to participate in victory celebrations. ${ }^{17}$ The article stated that they had been "invited" to celebrate but had refused because the war with Japan was not yet over. The Wah On Society was described as an "an old society with no political intentions," being a charity organisation with "no other power." The K.M.T. they noted in contrast was "a powerful political group"

Very little is known of the K.M.T. after 1932. Dr Chen made a return visit to Darwin from Sydney in 1933, but otherwise the society remained very quiet. In 1937, when the Territory Commission came to Darwin to gather evidence for the Payne and Fletcher report on the development of the Northern Territory, they interviewed two Chinese "community leaders" Chin Ack Ming of the Wah On Society and 66-year-old Lee Lim of the Chinese Commercial Society (Courier-Mail, 29 June 1937: 19; NAA: E1238, REPORT: 72).

\footnotetext{
${ }^{16}$ Chin Mon Dai (or Di) was, according to the birth certificate he used to enter Australia, 33 years old in 1931 and born in Brock's Creek, Northern Territory. He had been sent to China aged three and returned aged 13. In 1928, during a court case accusing Willie Howe of trafficking in opium, he said his father was Hakka and that he had a wife in Hong Kong (NTT, 17 January 1928: 1).

17 Thank you to Dr Catherine Churchman for translating this article.
} 
In 1940 the renewed Darwin Chinese Recreation Club was established as successor to the Chinese Recreation Club. ${ }^{18}$ The new President was T. See Kee, or Charles Tsang See Kee, a recent arrival in Darwin. See Kee also established the Chinese Chamber of Commerce in 1941 (Tsang See-Kee 1993). The DCRC officials included two women committee members, Dorothy Kwong and Lily Yuen, as well as the recently returned Gee Ming Ket. The club aims included a clear reference to past ruptures - it aimed to "unite and promote a better understanding firstly between the younger and older Chinese generation, and secondly between the Chinese and Australian community" (Northern Standard, 13 September 1940: 5). The new trustees were Chin Ack Ming of the Wah On Society, Albert Fong (previously on the K.M.T. executive) and Chin Loong Pak (Northern Standard, 1 November 1940: 3).

In post-war Darwin the Chung Wah Society was established in 1946 as the successor to the Wah On Society with some 100 members (Northern Standard 18 October 1946: 9). Albert Fong became the president of the Chung Wah Society, a position he held for many years. The Chung Wah Society today continues to be responsible for the Chinese temple and describes itself as a community-based, non-political organisation.

The Darwin branch of the K.M.T. was not re-established after World War II. There was no Darwin delegate sent to either the seventh K.M.T. regional convention in 1947 or the eighth regional convention in 1958 (Kuo \& Brett 2013: 138, 148). The DCRC was re-established, and in 1948 Charles See-Kee was President, Harry Chan Secretary and Albert Fong Treasurer. Harry Chan, son of Chin Fon, went on to become Mayor of Darwin in 1966. The post-war DCRC also had three female committee members: Lilyan Chan (wife of Harry Chan), Valerie Chin and Lucy Que Noy (Northern Standard, 30 July 1948: 3; see also Yee 2006). This later inclusion of women in huiguan associations was in keeping with international trends, with Seattle's Chong Wah Association appointing its first woman president in 1959 (Lai 2004: 63).

\section{Conclusion}

The Wah On Society and the K.M.T. survived an uneasy coexistence for more than a decade during which the shape of Chinese politics changed dramatically. This period saw the shift of the K.M.T. from the left to the right, the inclusion of the first women members in overseas Chinese politics and the transformation of Chinese workers from 'coolies' to union members. Perhaps more concerning for the Wah On Society, however, was not so much political differences as the prospect that the K.M.T. would usurp their role as community leaders in Darwin. Even while the divisions between the K.M.T., the merchants and the Wah On Society dominated newspaper debates, we can see on closer examination that some K.M.T. members were merchants and some were involved in running the Wah On Society. By having K.M.T. members Lena and Arthur Lee acting as secretary for the Wah On Society, the K.M.T. provided a useful service but also became well placed to influence the older society. The point of greatest convergence between the two

\footnotetext{
${ }^{18}$ The new association incorporated both the 1940 United Chinese Associations and the Chinese Recreation Club.
} 
was the result of family connections, in the passing on of businesses from father to son, which merged old merchant families with the K.M.T.

In 2012 Katrina Fong Lim was elected Lord Mayor of Darwin, following in the footsteps of her father Alec Fong Lim (Foong Soong Lim) who was Lord Mayor from 1984 to 1990 (Carment 2007). The fact that a Chinese woman had made it to the top position in local Darwin politics was noted by the Chung Wah Society. In congratulating Katrina on her election, Austin James Chin, President of the Chung Wah Society, commented: "the Fong Lim girls have shown that you don't have to have sons to carry on a dynasty" (Chin 2012). If in 1929 the question of Chinese women's involvement in politics had divided the K.M.T. and the Wah On Society, almost one hundred years later that issue was apparently resolved. 


\section{Appendix One: Darwin Delegates, K.M.T., 1929}

\begin{tabular}{|l|l|l|l|l|}
\hline Mandarin pinyin & Cantonese (Yale) & Characters & Taishanese & As in historical texts \\
\hline Top row, left to right & & & & \\
\hline ZHU Mingjie & JYU Mihng Giht & 朱明傑 & GEE Ming Ket & Gee Ming Ket (Tommy) \\
\hline YU Hong'an & YUH Huhng Ngon & 余洪安 & YEE Hoong On & $\begin{array}{l}\text { Charlie Yee Hong On } \\
\text { Charles Houng On }\end{array}$ \\
\hline KUANG Gengyuan & KWONG Gang Yuhn & 䢼庚源 & FONG Kang Yuen & Albert Fong \\
\hline LI Renggong & LEE Ying Kong & 李礽恭 & LEE Hang Gong* & Arthur Lee \\
\hline Seated, left to right & & & & \\
\hline LIU Weijiong & LAUH Waih Gwing & 劉維畑 & LAU Wai Kwing & unknown \\
\hline LIANG Yaozhu & LEUHNG Yiuh Chyuh & 梁瑤柱 & $\begin{array}{l}\text { LIENG Yeoh } \\
\text { Chee/Gee }\end{array}$ & unknown \\
\hline CHEN Mingxiang & CHAHN Mihng Seung & 陳明相 & CHIN Ming Sang & Ching Ah Sang (David) \\
\hline ZHONG Shaoqing & JUNG Siu Hing & 鍾少卿 & TSUNG Seoh Hen & $\begin{array}{l}\text { Chong Shue Hing } \\
\text { (Mrs Lena Lee) }\end{array}$ \\
\hline
\end{tabular}

Note: Thank you to Dr Kate Bagnall for the Mandarin and Cantonese versions, and to Dr Catherine Churchman for the Taishanese versions. The Taishanese spelling is based on how Taishan dialect might be transcribed in an English-speaking context.

* On the K.M.T. photograph the characters for Arthur Lee were mistakenly written as 李礽泰 or Lee Hang Hai in Taishanese.

\section{Appendix Two: Selected Lee Hang Gong family tree}

K.M.T. executive members are shown in italics.

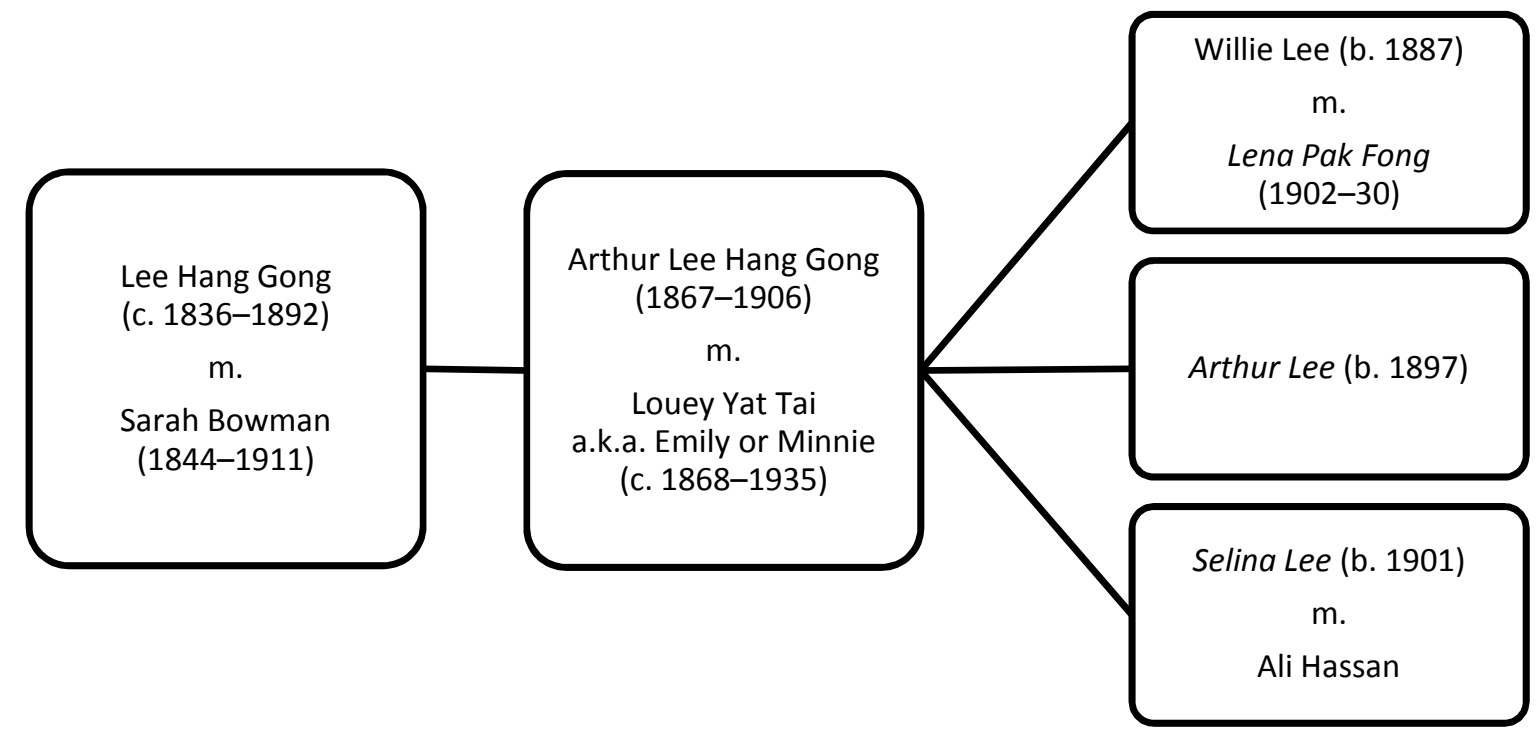




\section{References}

\section{Books, Articles and Theses}

Atkinson, Anne. 1995. "The Responses of Chinese Capital to Social and Economic Restrictions and Exclusions in Western Australia." In Histories of the Chinese in Australasia and the South Pacific, edited by Paul Macgregor: 29-46. Melbourne: Museum of Chinese Australian History.

Benton, Gregor. 2007. Chinese Migrants and Internationalism: Forgotten Histories, 1917-1945. Milton Park: Routledge.

Bergère, Marie-Claire. 1998. Sun Yat-sen. Redwood City, C.A.: Stanford University Press.

Brian Bernie. 2001, “The Northern Territory's One Big Union: The Rise and Fall of the North Australian Workers' Union, 1911-1972." Ph.D. thesis, Northern Territory University.

Chen, Duxiu. 1999. "The Way of Confucius and Modern Life." In Women in Republican China: A Sourcebook, edited by Hua R. Lan and Vanessa L. Fong: 5-7. Original essay published in 1916 (New York: M.E. Sharpe).

Cushman, J.W. 1984. "'A Colonial Casualty': The Chinese Community in Australian Historiography." Asian Studies Association of Australia Review 7(3): 100-13.

Fitzgerald, John. 2007. Big White Lie: Chinese Australians in White Australia. Sydney: University of New South Wales Press.

Fitzgerald, Shirley. 1997. Red Tape, Gold Scissors: The Story of Sydney's Chinese. Sydney: State Library of New South Wales Press.

Ganter, Regina with Julia Martínez and Gary Lee. 2006. Mixed Relations: Asian-Aboriginal Contact in North Australia. Crawley, W.A.: University of Western Australia Press.

Giese, Diana. 1995. Beyond Chinatown: Changing Perspectives on the Top End Chinese Experience. Canberra: National Library of Australia.

Lai, Him Mark. 2004. Becoming Chinese American: A History of Communities and Institutions. Walnut Creek, C.A.: Rowman AltaMira.

James, Barbara. 1989. No Man's Land: Women of the Northern Territory. Sydney: Collins Publishers Australia.

Jones, Timothy G. 2005. The Chinese in the Northern Territory. 3rd ed. Darwin: Charles Darwin University Press.

Kuo, Mei-Fen. 2013. Making Chinese Australia: Urban Elites, Newspapers and the Formation of Chinese-Australian Identity, 1892-1912. Clayton, Victoria: Monash University Publishing.

Kuo, Mei-Fen Kuo and Judith Brett. 2013. Unlocking the History of the Australasian Kuo Min Tang, 1911-2013. North Melbourne: Australian Scholarly Publishing.

Lowrie, Claire. 2009. "In Service of Empire: Domestic Service and Colonial Mastery in Singapore and Darwin, 1890s-1930s." Ph.D. thesis, University of Wollongong.

Macgregor, Paul. 2013. “Chinese Political Values in Colonial Victoria: Lowe Kong Meng and the Legacy of the July 1880 Election.” Journal of Overseas Chinese 9: 136-76.

Markus, Andrew. 1994. Australian Race Relations. Sydney: Allen \& Unwin.

Martínez, Julia. 1999. “Questioning 'White Australia': Unionism and Coloured Labour, 1911-37.” Labour History 76(4): 1-19. 
Martínez, Julia. 2000. "Plural Australia: Aboriginal and Asian Labour in Tropical White Australia, Darwin, 1911-1940.” Ph.D. thesis, University of Wollongong.

Martínez, Julia. 2003. "Separatism and Solidarity: Chinese and Aboriginal Sporting Connections." In Lost in the Whitewash: Aboriginal-Chinese Encounters in Australia, 1901-2001, edited by Penny Edwards and Shen Yuan Fang: 103-14. Canberra: Humanities Research Centre, Australian National University.

Martínez, Julia. 2011. "Patriotic Chinese Women: Followers of Sun Yat-sen in Darwin, Australia." In Sun Yat-Sen, Nanyang and the 1911 Revolution, edited by Lee Lai To and Lee Hock Guan: 200-218. Singapore: Institute of Southeast Asian Studies.

Reynolds, Henry. 2003. North of Capricorn: The Untold Story of Australia's North. Sydney: Allen \& Unwin.

Sowden, William. 1882. The Northern Territory As It Is: A Narrative of the South Australian Parliamentary Party's Trip. Adelaide: Thomas and Co.

Stone, Shane and Roger Steele. 1995. "Progress of the Chinese Community in the Northern Territory." Northern Perspective 18(1): 28-35.

Wilson, Helen J. 1996. "Ah Cheong (c1870-1935).” In Northern Territory Dictionary of Biography: Volume Three, edited by David Carment and Helen J. Wilson: 3-4. Darwin: NTU Press.

Yee, Glenice. 2006. Through Chinese Eyes: The Chinese Experience in the Northern Territory 18742004. Parap, N.T.: self-published.

Yong, C.F. 1977. The New Gold Mountain: The Chinese in Australia, 1901-1921. Richmond, South Australia: Raphael Arts.

Yung, Judy. 1995. Unbound Feet: A Social History of Chinese Women in San Francisco. Berkeley, C.A.: University of California Press.

\section{Archival Sources}

\section{National Archives of Australia (NAA)}

A1, Correspondence files (Department of External Affairs; Department of Home Affairs;

Department of the Interior) 1911/16191, Northern Territory. Taking of the Census of the N.T. 1912/10547, Chinese in Northern Territory. Disabilities under which they are working 1931/8945, Australian born Chinese Darwin representations re passport 1932/4524, Man Fong Lau and Coy

A711, Memorials of naturalization ([South Australia] General Registry Office) 1438, Yam Yan - Memorial of Naturalisation

E72, Correspondence files (Crown Law Office, Northern Territory) DL467, Northern Territory Crown Law Office - Inquest - Lena Lee

E752, Certificate Exempting from Dictation Test (Sub-Collector of Customs, Darwin) 1916/51, Certificate of Exemption from Dictation Test (CEDT) Chin Pack Sue 1916/61, CEDT William Lee Hang Gong

$1917 / 25$, CEDT Ming Ket 1921/20, CEDT Willie Howe 
1924/10A, CEDT Ching Ah Sang

1928/52, CEDT Hee Hong

125/14A, CEDT Willie Pak Poy and Alberta Pak Poy nee Chee Quee

1930/5, CEDT Yuen Tie Mooie, Wife of Albert Fong Goon

1938/4, CEDT Lee Lim

E1238, REPORT. Report of the Board of Inquiry into Land and Land Industries in the Northern Territory (the Payne Report) (Land Board, Northern Territory)

\section{Other Archival Sources}

Hassan (nee Lee), Selina. 1979. Transcript of Interview with Barbara James. NTRS 226, TS 236. Northern Territory Archives Service, Darwin.

Lee, Henry. 1981. Transcript of Interview with S. Saunders. NTRS 226, TS 261. Northern Territory Archives Service, Darwin.

Litchfield, Jessie. n.d. "Press Collect.” Unpublished Manuscript. Litchfield Papers, MS 132. Canberra: National Library of Australia.

Tsang See-Kee, Charles. 1993. Interviewed by Diana Giese in the Post-war Chinese Australians oral history project, Canberra: National Library of Australia.

\section{Newspapers}

Advertiser, Adelaide

Brisbane Courier

Cairns Post

Courier-Mail, Brisbane

Daily News, Perth

Northern Standard, Darwin

Northern Territory Times and Gazette, Darwin

Northern Territory Times, Darwin

Register, Adelaide

Sydney Morning Herald

Townsville Daily Bulletin

Tung Wah Times 東華報 Donghuabao, Sydney

West Australian, Perth

\section{Online Sources}

Commonwealth Bureau of Census and Statistics. 1921. Census of the Commonwealth of Australia: Census Bulletin No. 7, Northern Territory. Melbourne: Government Printer. Accessed 1 June 2014. http://abs.gov.au/AUSSTATS/abs@.nsf/DetailsPage/2111.01921?OpenDocument.

Commonwealth Statistician. 1933. Census of the Commonwealth of Australia - 30th June, 1933: Volume 1, Part VII Territories. Accessed 1 June 2014.

http://abs.gov.au/AUSSTATS/abs@.nsf/DetailsPage/2110.01933?0penDocument. 
Chin, Austin James. 2012. "Annual Report of the President, 2011-2012.” Chung Wah Society, Darwin, 28 October. Accessed 20 February 2014.

http://www.chungwahnt.asn.au/uploads/pdfs/2012\%20Presidents\%20Report.pdf.

Carment, David. 2007. "Fong Lim, Alexander (Alec) (1931-1990).” Australian Dictionary of Biography. Canberra: National Centre of Biography, Australian National University. Accessed 20 February 2014. http://adb.anu.edu.au/biography/fong-lim-alexander-alec12502/text22495.

Couchman, Sophie. 2012. “Fong Sui Wing (c. 1860 - 1920).” Chinese-Australian Historical Images in Australia. Accessed 12 February 2014.

http://www.chia.chinesemuseum.com.au/biogs/CH00950b.htm.

Gee, Ashley. 2008. “Fong Sui Wing \& Young See (2nd Wife) \& Children.” Gee Family History (blog), 18 December. Accessed 12 February 2014.

http://geefamilyhistory.blogspot.com.au/2008/12/fong-sui-wing-young-see-2ndwife.html. 